\title{
GREEN MANAGEMENT: THE REALITY OF BEING GREEN IN BUSINESS
}

\section{GESTIÓN VERDE: LA REALIDAD DE LA SOSTENIBILIDAD ECOLÓGICA EN LA GESTIÓN GERENCIAL}

\author{
Ben Tran ${ }^{1}$
}

\begin{abstract}
Green management and going green are not as clear cut and easy as hyped by the general media. While going ecologically green is indeed beneficial and appropriate, the process and procedure of becoming green is anything but easy. Firstly, turning green is largely not a legal requirement, but a voluntary process. Thus, even though LEED (which is by far the more publicly known green certification standard) governs the certification of the green management effort, it is not a compulsory condition for practitioners to go green. Secondly, even with the encouragement of incentives to comply, practitioners are skeptical in becoming green due to: (a) a lack of true understanding of the benefit of ecologically friendly procedures (the practice of profits versus the theory of benefits); (b) lack of short term gain in life cycle costing (practitioners want instant incentives); and (c) mostly, because it is not a legal requirement for the vast majority of municipalities.
\end{abstract}

Keywords: Green management, green business practices, barriers toward green management, encouragement \& incentives for green management, LEED Certification.

\section{RESUMEN}

La gestión ambiental sostenible y el tornarse ecológico no es tan claro ni factible como lo pregona la prensa. Mientras que volverse ecológicamente "verde" es sin duda beneficioso y apropiado, el proceso y el procedimiento de hacerlo es todo menos fácil. En primer lugar, transformarse ecológicamente eficiente no es un requerimiento legal, sino un proceso voluntario. Entonces, mientras la certificación LEED (Leadership in Energy and Environmental Design, que es con mucho la certificación ecológica estándar más conocida) lidera los esfuerzos para la certificación de gestión ecológica, ésta no es una condición obligatoria para los involucrados. En segundo lugar, aún con el estímulo de incentivos para cumplir con los requerimientos, los gestores dudan en integrarse ecológicamente debido a lo siguiente: (a) falta entender correctamente los beneficios de los procedimientos ecológicos (la práctica de las ganancias versus la teoría de los beneficios); (b) ausencia de beneficios a corto plazo dentro del costo del ciclo de vida (los actores desean incentivos inmediatos); y (c) mayormente, no es un requisito legal en la gran mayoría de las municipalidades.

Palabras claves: Gerencia ecológica, prácticas empresariales ecológicas, barreras a la gestión ecológica, estímulos e incentivos para la gestión ecológica, certificación LEED

1. Doctor of Psychology, Marshall Goldsmith School of Management at Alliant International University, San Francisco, USA; <tranconsulting@ gmail.com>. 


\section{INTRODUCTION}

Green is in. Green is in vogue. Green is the new black. Consumers are asking for it. Organizations are requesting it. Green managements ${ }^{1}$ are demanding it. The future of business is being built on green and social responsible organizations. The green bandwagon is overloaded with posers and images of green without the true understanding of what green means, the methodologies of achieving green, and the applicability of green management.

Nevertheless, being green is fast becoming an essential component of almost every commercial building and interior design projects. At the same time, more architects and designers are looking for high quality green products in order to meet new green building ${ }^{2}$ guidelines, which continue to evolve at a rapid pace and, as a result, there are many entities involved in establishing standards and certifying that they have been met. With that said, green, as applied here, is a term now widely used to describe buildings designed and constructed with minimal negative impact to the environment and with an emphasis on conservation of resources, energy efficiency ${ }^{3}$ and healthful interior spaces. Green can also be used to describe sites that are designed in an environmentally sensitive manner with minimal damage to the surroundings.

The question of why green management matters is addressable via two approaches, namely the science and the arts. However, the arts approach will be utilized versus the science due to the purpose and the applicability of the question pertaining to the business management industry. Alternative perspectives can be employed via the science approach but this will not be included here. Thus, from the business management

1 Definitions of green management terminologies have been discussed with James Tefend, a licensed Principal Architect in the State of California.

2 A green building is a building that minimizes impact on the environment through resource conservation and contributes to the health of its occupants. Green buildings have comfortable, aesthetically pleasing and healthful environments.

3 Energy efficiency is the ratio of energy output of a conversion process or of a system to its energy input. perspective, green management matters due to the so called triple bottom line. The triple bottom line consists of the environmental benefits, positive economics effect, and healthy societal images.

The triple bottom line (or "TBL", "3BL", or "people, planet, profit") captures an expanded spectrum of values and criteria for measuring organizational (and societal) success: economic, ecological and social. The phrase was coined by John Elkington (Elkington, 1994), co-founder of the business consultancy SustainAbility, in his 1998 book, Cannibals with Forks: the Triple Bottom Line of 21st Century Business. Triple Bottom Line accounting attempts to describe the social and environmental impact of an organization's activities, in a measurable way, to its economic performance in order to show improvement or to make evaluations more indepth. However, there are currently few standards for measuring these other impacts (The Dictionary of Sustainable Management, N.Y. 2009). However, the discussion of the triple bottom line will not be included in this work.

\section{THE CONCEPT OF GREEN MANAGEMENT}

The concept of green management is gaining attention in the academia. As such, research and theoretical contributions have started to take shape in its literature establishment. However, there exists a scarcity in academic literature concerning green management from the perspective of practitioners. Such concerns are the ins-and-outs of green management, and its purpose being to get to the triple-bottom-line.

Green management is not a concept describing new business management style. Green management describes the construction (the construction process to be exact) of businesses. In other words, business management styles focus on the recruiting of, the management of, and the utilization of competent and talented employees to produce profits on behalf of the business. Green management, on the other hand, is the couture method of producing profits.

Considering the above, the purpose of this article is to explore and understand green management and the 
purpose of green management, and not the triple-bottom-line. The analysis and understanding and the purpose of green management will be explored through interviews with a licensed architect, the process of LEED certification (the leading, most well known green management standard), and case studies of Google, VMware, and Sony. As such, a detailed analysis of green management (what green management is and what is not), and the history of LEED (the creation and the limitation) will be covered. In so doing, this article will address two questions, based on the perspective of the practitioners: First, what are the encouragements and incentives for green management? Secondly, what are some of the concerns, confusions, and barriers to green management? Furthermore, this article will discuss three examples of corporate companies that have implemented green management practices.

\section{ENVIRONMENT: ENVIRONMENTAL POSITIONING, ENVIRONMENTAL IMPACT, AND GREEN BUILDING PRACTICE}

In the history of business management, companies are turning green at an increasing rate due to an unprecedented reason, which is not directly based on profitability, longevity, or sustainability ${ }^{4}$. The unprecedented urgency arises from matters such as environment, sustainability, branding, and stewardship, which are causing dramatic changes in how companies operate. Organizations of all shapes and sizes are working to turn green their processes, products, facilities, and direct sustainable business practices into competitive advantages.

4 Sustainability is a concept that can be traced back to President Theodore Roosevelt who stated in 1910 the following: "I recognize the right and duty of this generation to develop and use the natural resources of our land; but I do not recognize the right to waste them, or to rob, by wasteful use, the generations that come after us." In 1987, the United Nations World Commission on Environment and Development (The Brundtland Commission) defined a sustainable development as one that "meets the needs of the present without compromising the ability of future generations to meet their own needs." Sustainability has three interdependent dimensions relating to the environment, economics and society - often referred to as the triple bottom line.

\section{Environmental Positioning: Branding}

Green management is the new branding strategy for establishing a reputation for one self in the dog-eatdog world of businesses. The reliance on expertise, quality of customer service, and quality of the product service is no longer enough. Businesses nowadays are downplaying the message of profit-hungry and communicating the message of being environmentally conscious. In other words, businesses are expressing through actions that not only being environmental friendly is necessary, but also preserving the environment is paramount. It is a win-win situation where businesses can grow and give back. Hence, going green, in the long run, pays off through tax incentives and the values of green management implementations.

In other words, when it comes to branding going green, it is to practitioners a story for public relations machines; it is a story that communicates to three paramount audiences. The first is their potential clients. Clients nowadays are specifically hunting for and paying extra for the price of green commercial buildings. The second is their potential consumers. Consumers (society at large and business' clients) are specifically favoring businesses that are green, or going green, because it gives them the satisfaction of interacting with companies they perceive to be noble in helping the environment. The third is their potential skills-andknowledge based participants. Skills-and-knowledge based participants are the practitioners' bread-andbutter; they are workers often more savvy and green demanding. Thus, they are more attracted to working for practitioners' that are green savvy. Branding helps cement a company's public image as being green therefore making it more successful. For example, here are some telltale statistics:

1. $79 \%$ of U.S. consumers say that a company's environment practices influence the products and services they recommend to others.

2. $64 \%$ of consumers worldwide say they are willing to pay a higher price for goods and services that produce lower greenhouse gas emissions, according to a study by Accenture; 
3. A survey of consumers in seventeen (17) countries across five (5) continents by market research firm TXN found that $94 \%$ of Thai respondents and $83 \%$ of Brazilian were willing to pay more for environmental friendliness, although only $45 \%$ of British and $53 \%$ of US respondents were willing to pay more to help the environment.

4. Consumers expect to double their spending on green products and services within one year, totaling an estimated $\$ 500$ billion annually, or $\$ 43$ billion per month, according to the ImagePower Green Brands Survey (Makower, 2009: 25-26).

However, success does not come easy for, despite mounting pressure on businesses to prove their faithfulness to the Earth, managers do not share a common understanding of what this might mean in their own companies. Many continue to see environmentalism against the backdrop of an adversarial public arena or as a struggle over ever-stricter emissions codes and wildly varying punishments for misconduct. Still, managers do share some new and growing sophistication about what the public expects. In 1985, when the National Wildlife Federation's Corporate Conservation Council began to offer environmental awards to businesses, several corporations nominated themselves for what they obviously thought a remarkable feat -compliance with government regulations (Kleiner, 1991). Nowadays, a company does not expect to be considered "environmental friendly" unless it is moving not only beyond the letter of the law, but ahead of its industry and many of its consumers.

For instance, according to Art Kleiner (1991), Pacific Gas and Electric Company recently decided that energy conservation is a more profitable investment than nuclear power. Du Pont converted its in-house pollution-prevention program into a consulting operation. Also, McDonald's made its well-publicized move from plastics to paper the cornerstone of a much broader, and less visible, waste-reduction strategy. The managers of these businesses clearly have come to believe that environmentalism has something to offer, that it is not just the other way around. The "greenness" of a company, then, does not really start in any single dem- onstration of concern to produce an environmentally kind product — paper over plastic, for example. Rather, it is embodied in a company's willingness to experiment continually with the life cycles of its products.

Nonetheless, green management is not the repackaging or the reinventing approaches to business, nor business management. Even more, green management is not a concept describing new business management style. Thus, the established founding fathers of business management, Edgar H. Schein, Gareth Morgan, Peter Drucker, Frederick Taylor, Henri Fayol, Peter Senge, and the like need not be ignored. Green management is simply the rethinking, or more accurately, being more mindful of how organizations are operating (or a lack thereof) with respect to the environment. It is not the human factors within the organization that are being managed, but the components of the organization that is being managed by green management.

In other words, the concept of green management consists of three components: green building, green energy ${ }^{5}$, and green waste. Green building is the practice of increasing the environmental efficiency in which structures use resources (energy, water, and materials) while reducing impact on human health and the environment during the life cycle of the building. This can be done through better setting, design, construction, operation, maintenance, and waste removal (Frej, 2005, pp. 4-8). A similar concept is natural building, which is usually on a smaller scale and tends to focus on the use of natural materials that are available locally (Hopkins, 2002). Other commonly used terms include sustainable design and green architecture. The related concepts of sustainable development and sustainability are integral to green building. An effective green building can lead to:

1. Reduced operating costs by increasing productivity and using less energy, materials, and water.

2. Improved public and occupant health due to improved indoor air quality.

5 Green Energy, also known as green power, is the electricity generated from renewable energy sources (solar, wind, biomass, geothermal, and hydroelectric). 
3. Reduced environmental impacts by, for example, lessening storm water runoff and reducing the urban heat island effect.

Practitioners of green buildings often seek to achieve not only ecology but aesthetic harmony between a structure and its natural and built surrounding environment, although the appearance and style of sustainable buildings is not necessarily distinguishable from their less sustainable counterparts.

\section{Environmental Impact}

Green building practices aim to reduce the environmental impact of buildings. Buildings account for a large amount of land use, energy and water consumption, air and atmosphere alteration. In the United States more than two million acres of open space, wildlife habitat, and wetlands are developed each year (Frej, 2005). As of 2006, buildings used $40 \%$ of the total energy consumed in both the U.S. and European Union (Baden, Waide, Fairey, \& Laustsen, 2006; U.S. Department of Energy, 2008).

In the U.S., 54\% of that percentage was consumed by residential buildings and $46 \%$ by commercial buildings (U.S. Department of Energy, 2007). In 2002, buildings used approximately $68 \%$ of the total electricity consumed in the United States, with 51\% for residential use and $49 \%$ for commercial use. $38 \%$ of the total amount of carbon dioxide in the United States can be contributed to buildings, $21 \%$ from homes and $17.5 \%$ from commercial uses. Buildings account for $12.2 \%$ of the total amount of water consumed per day in the United States.

Considering these statistics, according to the U.S. Environmental Protection Agency Green Building Workgroup (2004), also known as the EPA, reducing the consumption of natural resources in buildings and the amount of pollution given off is seen as crucial for future sustainability. The environmental impact of buildings is often underestimated, while the perceived costs of green buildings are overestimated. A recent survey by the World Business Council for Sustainable Development finds that green costs are overestimated by $300 \%$, as key players in real estate, and construction estimate the additional cost at $17 \%$ above conventional construction, more than triple the true average cost difference of about $5 \%$ (World Business Council for Sustainable Development, 2007).

Porter and van der Linde (1999) state that, like defects, pollution often reveals flaws in the product design or production process. Efforts to eliminate pollution can therefore follow the same basic principles widely used in quality programs: use inputs more efficiently, eliminate the need for hazardous, hard-tohandle materials, and eliminate unneeded activities. In a recent study of major process changes at ten manufacturers of printed boards, for example, Porter and van der Linde (1999) found that pollution-control personnel initiated thirteen of thirty-three major changes. Of the thirteen changes, twelve resulted in cost reduction, eight in quality improvements, and five in extension of production capabilities (King, 1994). It is not surprising that total quality management (TQM) has become a source of ideas for pollution reduction that can create offsetting benefits. For instance, the Dow Chemical Company explicitly identified the link between quality improvement and environmental performance by using statistical-process control to reduce the variance in process and to lower waste (Porter \& van der Linde, 1999).

This example, according to Porter and van der Linde (1999), illustrates why the debate about the relationship between competitiveness and the environment has been framed incorrectly. Policy makers, business leaders, and environmentalists have focused on the static cost impacts of environmental regulation and have ignored the more important offsetting productivity benefits from innovation. As a result, they have acted too often in ways that unnecessarily drive up costs and slow down progress on environmental issues. This static mind-set has thus created a self-fulfilling prophecy leading to ever more costly environmental control. Regulators tend to set rules in ways that deter innovation. Companies, in turn, oppose and delay regulation instead of innovating to address them. The whole process has spawned an industry of litigators and consultants that drains resources away from real solutions. 


\section{Green Building Practices}

Green building brings together a vast array of practices and techniques to reduce and ultimately eliminate the impacts of constructions on the environment and human health. It often emphasizes taking advantage of renewable resources. Some of them are sunlight through passive solar ${ }^{6}$, active solar ${ }^{7}$, and photo voltaic ${ }^{8}$ techniques, as well as using plants and trees through green roofs, rain gardens, and for reduction of rainwater run-off. Many other techniques are applied as well such as using packed gravel for parking lots instead of concrete or asphalt to embrace replenishment of ground water.

However, effective green buildings are more than just a random collection of environmental friendly technologies (Levin, 2008). They require careful, systemic attention to the full cycle of impacts of the resources contained in the building and to the resource consumption and pollution emission over the building's complete life cycle. On the aesthetic side, green architecture or sustainable design is the philosophy of designing a building that is in harmony with the natural features and resources surrounding the site. There are several key steps in designing sustainable buildings, namely the specification of "green" building materials from local sources, reduced energy loads, mechanical system's optimization and generation of on-site renewable energy and re-utilization of on-site materials.

\section{Green Building Materials}

Green building materials considered to be "green" include rapidly renewable plant materials like bamboo and straw, lumber from forests certified to be sustainably managed, dimensioned stone ${ }^{9}$, recycled stone,

6 Passive Solar technologies are means of using sunlight for useful energy without use of active mechanical systems.

7 Active Solar technologies are when mechanical systems are used in conjunction with the solar technologies to provide heating cooling/ventilation (an example would be photovoltaics such as solar panels).

8 Photovoltaic (PV) is the field of technology and research related to the application of solar cells for energy by converting sunlight directly into electricity.

9 Dimension Stone is a natural stone or rock that has been selected and fabricated to specific sizes and shapes. recycled metal, other products that are non-toxic, reusable, and/or recyclable (Trass ${ }^{10}$, Linoleum ${ }^{11}$, sheep wool, panels made from paper flakes, compressed earth block, adobe, baked earth, rammed earth ${ }^{12}$, clay, vermiculite, flax linen, sisal, sea grass, cork, expanded clay grains, coconut, wood fiber plates, calcium stone, etc.). Building materials that are extracted and manufactured near to the site minimize the energy embedded in their transportation and are seen as being the "greenest of the green".

\section{Reduced Energy Use}

Green buildings often include measures to reduce energy use. To increase the efficiency of the building envelope ${ }^{13}$, they may use high-efficiency windows and insulation in walls, ceilings, and floors. Another strategy is passive solar building design ${ }^{14}$, which is often implemented in low-energy homes. Designers orient windows and walls, place awnings, porches, and deciduous trees (Simpson, 2002) to shade windows and roofs during the summer while maximizing solar gain in the winter. In addition, effective window placement (day-lighting) can provide more natural light and lessen the need for electrical lighting during the day. Solar water heating can further reduce energy loads. Finally, on site generation of renewable

10 Trass is a product from a volcanic tuff, or solidified volcanic ash, from the region of Eifel, in the West Rhine region, used as hydraulic mortar. It is made out of gray or cream-colored pumiceous dust.

11 Linoleum is a floor covering made from solidified linseed oil (linoxyn) in combination with wood flour or cork dust, spread over a burlap or canvas backing.

12 Rammed earth, also known as cob, pise de terre or simply pise, is a type of construction material. Rammed earth is an old method of home construction where one simply pounds the earth densely compacted to make a retaining wall.

13 Building envelope is the separation between the interior and the exterior environments of a building. It serves as the outer shell to protect the indoor environment as well as to facilitate its climate control.

14 Passive solar buildings aim to maintain interior thermal comfort throughout the sun's daily and annual cycle while reducing the requirement for active heating and cooling systems. Passive solar building design is one part of green building design, and does not include active systems such as mechanical ventilation or photovoltics, nor does it include life cycle analysis. 
energy ${ }^{15}$ through solar power, wind power, hydro power ${ }^{16}$, or biomass ${ }^{17}$ can significantly reduce the environmental impact of the building. Power generation is generally the most expensive feature to add to the building.

\section{Reduced Waste}

Green architecture also seeks to reduce waste of energy, water, and materials. During the construction phase, one goal should be to reduce the amount of material going to landfills. Well-designed buildings also help reduce the amount of waste generated by their occupants as well as providing onsite solutions, such as compost bins, to reduce matter going to landfills. To reduce the impact on wells or water treatment plants, several options exist. Greywater ${ }^{18}$ - wastewater from sources such as dish washing or washing machinescan be used for subsurface irrigation or, if treated, for non-potable purposes.

Centralized wastewater treatment systems can be costly and use a lot of energy. An alternative to this process is converting waste and wastewater into fertilizers, which avoid these costs and show other benefits. By collecting human waste at the source and running it to a semi-centralized bio-gas plant with other biological waste, liquid fertilizer can be produced. This concept was demonstrated by a settlement in Lubeck, Germany, in the late 1990s. Practices like these provide soil with organic nutrients and create carbon sinks that

15 Renewable energy is energy generated from natural resources - such as sunlight, wind, rain, tides, and geothermal heatwhich are renewable. Renewable energy technologies include solar power, wind power, hydroelectricity, micro hydro, biomass, and bio-fuels.

16 Hydropower, hydraulic power, or water power is power derived from the force or energy of moving water, which may be harnessed for useful purposes.

17 Biomass refers to living and recently dead biological material that can be used as fuel or for industrial production. Most commonly, biomass refers to plant matter grown to generate electricity or produce bio-fuel, but it also includes plant and animal matter used for production of fibers, chemicals, or heat.

18 Greywater, also known as sullage, is non-industrial wastewater generated from domestic processes such as dish washing, laundry, and bathing. Greywater comprises $50 \%-80 \%$ of residential wastewater. remove carbon dioxide from the atmosphere, offsetting greenhouse gas emission. Producing artificial fertilizer is also more costly in energy than this process (Lange, Grottker, \& Otterpohl, 1998).

\section{THE ECONOMICS}

According to Kleiner (1991), Joel Makower writes in The Green Consumer Supermarket Guide that every purchase is a vote for or against the environment. In the emerging political culture of America, a consumer's search for ecologically benign products can often seem as capricious as the loyalties reflected in political polls. Green consumers certainly do not stick to particular brands. For instance, Mobil's "Hefty" plastic bags soared in popularity when the company pronounced them biodegradable and consumers saw them as a panacea for landfills. When news emerged that the bags decomposed only partially, often creating worse problems, sales dropped.

The exact number of green consumers is unknown, but their numbers undoubtedly appear to be growing. Gallup polls conclude that more than $75 \%$ of U.S. consumers include environmentalism in their shopping decisions -an impressive number, though some of this data no doubt reflects the desire of many respondents to appear responsible. In any case, it would be foolish to dismiss the recent wave of ecological concern among consumers as a passing fad. There are too many reminders around us of what many familiar products and packaging do to the environment: beach sewage, crowded landfills, smoldering piles of discarded tires, and poisoned water.

Each news story prompts a natural impulse to support alternative products. If consumers accept that chlorofluorocarbons damage the ozone layers, they implicitly expect companies to search for alternatives to aerosol sprays and new technologies for refrigerator cooling systems. Unfortunately, there is usually no technical quick fix, and the demand for one could actually hamper efforts to improve a company's environmental record. The aerosol sprays that replaced CFCs, for example, often contain butane, which not only pollutes the air but can also explode in people's faces. 
Or consider the widely cited case of McDonald's packaging. Makower points out that it was not for ecological reasons that McDonald's decided to switch in October 1990 from plastic "clamshell" hamburger boxes to paper wrappers. McDonald's had researched the matter three years before and determined that styrene packages actually were more recyclable than paper. But, top executives changed their minds because their customers just did not "feel good about" styrene, as Edward H. Rensi, MsDonald's U.S. company president put it. Especially interesting was a letter-writing campaign conducted by groups of school children nationwide. That protest, of course, did not really represent the "voting" of the general public; indeed, the year before U.S. sales increased. So the company gave in not to informed, actual pressure, but to anxiety about misguided, potential pressure ${ }^{19}$.

None of this is to say that companies should throw up their hands. It is to caution managers -at least those who are serious about the environment - that they cannot let the shifting attitudes of consumers dictate their actions, even though it is consumers who are pressuring them to act. It is more responsible to judge the environmental effects of products by using scientifically rigorous methods that are now emerging. Life-cycle costing attaches a monetary figure to every effect of a product: landfill costs, potential legal penalties, degradation in air quality, and so on. Projects likely future costs as much as cash-flow analysis does. Then, it compares two or more products or packaging alternatives based on its projections.

To be sure, much of the data used in life-cycle analysis promises to leave managers feeling uncertain, especially with respect to public health. But the exercise gives a company at least some sense of the potential environmental damage or financial returns - or boththat could result from their investment. For example, Bailey points to several pilot projects - whose sponsors range from a plastic industry trade association to the New Jersey Department of Environmental Protection

19 For a list of the top fifty (50) (United States and International) WaveRiders (companies that have gone or are going green), please refer to Daniel C. Esty and Andrew S. Winston's Green to Gold: How Smart Companies Use Environment Strategy to Innovate, Create Value, and Build Competitive Advantage. -on the relative merits of paper or plastic shopping bags. When all environmental factors are calculated in terms of their estimated economic values - storage space, the susceptibility of the bags to vermin infestation, present and future recycling facilities - the choices may well vary for different supermarkets.

Based on the above, at its best, McDonald's engages in just such experimentation. It is looking behind the counter to the $80 \%$ of its waste that, according to its own figures, the customer never sees. It has initiated a pilot project in composting food scraps; it will be testing refillable coffee mugs; and it is considering introducing starch-based, thus biodegradable, cutlery. There are other procedures and manufacturers are engaging in useful experiments as well.

Many agribusinesses have become interested in alternative pest controls. As it happens, farms that use relatively few pesticides, applied only when there is evidence of insect infestation, are more productive than farms using indiscriminate aerial spraying. In fact, the pest control industries themselves could reexamine their products. An agricultural chemical company might, for instance, stop selling its products by the pound and instead will concentrate on integrated pest management. Even when sold at a premium price, this kind of service would be worth more to the crop grower than a warehouse full of powder.

In a similar example of corporate rethinking, Nissan convened an eclectic group of people, through a computer conferencing network to brainstorm about how an environmentally responsible car company might behave. Participants included science writers, ecologists, energy experts, and anthropologists, many with long-standing reputations in the study of ecology or energy efficiency. The printouts of their "discussions" revealed how environmental talk can actually tease out — and make more acceptable- product ideas no car company would likely think on its own. Many suggestions were futuristic, of course, and not much attention was paid to the economic justifications of any particular project. But when product designers are forced to think deeply about the impact of their products on the planet, they cannot but consider anew what their products do and how to improve their performance. 


\section{THE SOCIETY}

According to Kleiner (1991), during the two years before the 1984 Bhopal gas leak, Union Carbide denied reports of faults in the plant. Even the local toxicologist had been given no data about how lethal was the escaping gas. An open information policy might have spurred enough attention to prevent the leak. It almost certainly would have stimulated the community around the plant to put emergency defensive measures in place, which might have saved lives. It also would have made the company less guilty to charges of criminal negligence if they had open information policy to implement.

Indeed, if any one thing can protect a company from environmental disaster, it is participation in an open flow of information about potential problems, both inside and outside major facilities. When asked what is important to them, even the most litigious citizens' hazardous-waste group leaders will say that compensation is a secondary concern. Citizen's groups generally do not ask for punitive damages, not at first, but rather for health screening and independent epidemiological and toxicological studies to be conducted by people whose credibility they trust. They care much more about being protected from them, and therefore they depend on open information.

Companies, for whatever reasons, tend to resist this approach. In part, because open disclosures cut against the grain. Such disclosures can prompt the fear that one would give away something to a competitor or give environmental groups reasons to go after their businesses. Not until 1986, when the Superfund Amendments and Reauthorization Act (SARA) required companies to report their emissions levels of 300 chemicals, have companies had any consistent way to experience the benefits of disclosure. It turns out that these are considerable.

SARA established no legal limits on emissions - limits are established by other laws and regulations-, but all emissions must be publicly reported under Title III of the act, the Emergency Planning and Community Right-to-Know Provision. Reports also go into a database maintained by the Environmental Pro- tection Agency, known as the Toxic Release Inventory. Thus, for example, any researcher or citizen could have found out how much vinyl chloride the Vista Chemical Company released from its Aberdeen, Mississippi plant since 1989, or in what year Intel stopped using arsine gas for its semiconductor-ion-implant processes in its facility in Chandler, Arizona (Kleiner, 1991). SARA is one among the available associations/companies that govern this arena (Citizen Decca, N.Y.).

A few national groups, including Citizen Action and the National Wildlife Federation, have published lists of companies they consider egregious polluters. But local groups are just beginning to learn how to use the data. According to the first comprehensive report on the effects of Title III, Managing Chemical Risks, prepared by the Center for Environmental Management at Tufts University, there may even be some inertia here. The report concluded that only few companies received any demand for chemical information from private citizens, and that following provision of information, no additional questions o concerns were raised (Kleiner, 1991).

But within companies, SARA has had enormous, unexpected effect. The Tufts research group studied eight companies in detail, including Dow Chemical, Intel, Occidental Chemical, Vista Chemical, and Mastic Corporation. They found that the mere gathering of information prompted mutual technical assistance in the company, the transfer of good practices from division to division, and increased contact with customers and suppliers. Although SARA requires no communityrelations efforts, most of the companies developed outreach efforts nonetheless.

Dow Chemical's story is particularly revealing. Until 1984, Dow had never actually tallied up its pollutions. The company finally did so only under duress, when along with 85 other chemical companies it was formally requested to report major emissions to a Congressional subcommittee, chaired by environmentalist Henry Waxman. Dow's executives discovered that the company was releasing ten million pounds of dangerous chemicals into the environment. They remember that discovery vividly, because it forced them to look critically at a whole host of the company's operations: 
after investing heavily in scrubbers, filters, and incinerators, they were still releasing millions of pounds of chemical wastes.

Soon Dow began a concerted effort to reduce its emissions more effectively and has now cut its pollution by more than half, saving the company hundreds of thousands of dollars in the process. Moreover, Dow assigned its local plant managers the task of meeting with community leaders. Dow learned, as its environmental officer Jerry Martin put it, that the public will accept reasonable process. As such, SARA's success opens up the question of how other informationgathering processes can lead to voluntary efforts that would make a difference. For example, one of the biggest problems with toxic chemicals is determining their compounded epidemiological effect. So much of the data is gathered in separate studies that are not reconciled together, and many important facts are hidden by non-disclosure clauses in corporate lawsuits.

But imagine what would happen if most companies disclosed their epidemiological data about chemical toxic effects, including anonymous data previously suggested, and then compiled into a single database. It might then be possible to link chemicals and, perhaps more important, combinations of chemicals, to health effects. Think of the kind of research done on prescription medications and the discoveries about how dangerously medicines tend to catalyze one another. The public and the pharmaceutical company industry want people to be able to ingest these chemicals with a reasonable level of confidence.

\section{THE BARRIERS TOWARD GREEN MANAGEMENT: STATIC MIND-SET AND BAD REGULATION}

The first problem that prevents companies from going green, according to Michael E. Porter and Claas van der Linde (1999), is adversarial process, which locks companies into static thinking and systematically pushes industry estimates of the costs of regulation upward. A classical example occurred during the debate in the United States in the 1970 Clean Air Act. Lee lacocca, then executive vice president of the Ford Motor Company, predicted that compliance with the new regulation would require huge price increases for automobiles, force U.S. production to a halt by 1975 , and severely damaged the U.S. economy. The 1970 Clean Air Act was subsequently enacted, and lacocca's dire predictions turned out to be wrong. Similar stories are common.

Static thinking causes companies to fight environmental standards that actually could enhance their competitiveness. Most distillers of coal tar in the United States, for example, opposed 1991 regulations requiring substantial reductions in benzene emission. In so doing, instead of suffering a cost increase, Aristech Chemical Corporation of Pittsburgh, Pennsylvania, saved itself $\$ 3.3$ million (Porter \& van der Linde, 1999). Similar success stories contradicting the static mind-set are common: the Phone-Poulenc ${ }^{20}$ plant in Chalampe, France (Porter \& van der Linde, 1999); Dow Chemical's ${ }^{21}$ California complex scrubs (Dorfman, Muir, \& Miller, 1992); 3M22 (Boroughs \& Carpenter, 1991: 46; Sheridan, 1992: 43); Ciba-Geigy Corporation ${ }^{23}$, Raytheon ${ }^{24}$, and Hitachi ${ }^{25}$ (Porter \& van der Linde, 1999), just to name a few.

The second problem that prevents companies from going green is the current system of environmental regulation in the United States, which, according to Porter and van der Linde (1999), often deters innovative solutions or renders them impossible. The problem with regulation is not its strictness; it is the way standards are written and the sheer inefficiency with

20 Rhone-Poulenc invested 76 million franc and in return has generated annual revenues of about 20.1 million francs (Porter \& van der Linde, 1999).

21 Dow Chemical invested $\$ 250,000$ and in return the company saved \$2.4 million annually (Dorfman, Muir, \& Miller, 1992).

$223 \mathrm{M} \mathrm{improved} \mathrm{resource} \mathrm{productivity} \mathrm{and} \mathrm{shortened} \mathrm{its} \mathrm{time} \mathrm{to} \mathrm{mar-}$ ket because its water-based product did not have to go through the approval process for solvent-based coatings (Boroughs \& Carpenter, 1991, p. 46). 3M also reduced hazardous wastes by 110 tons per year at almost no cost, yielding an annual savings of more than \$200,000 (Sheridan, 1992: 43).

23 Ciba-Geigy Corporation not only reduced pollution, but also increased process yields by $40 \%$, with an annual savings in cost of $\$ 740,000$ (Porter \& van der Linde, 1999).

24 Raytheon's new method improved average product quality while also lowering operating costs (Porter \& van der Linde, 1999).

25 Hitachi cut back the number of parts in a washing machine by sixteen percent, and the number of parts in a vacuum cleaner by thirty percent (Porter \& van der Linde, 1999). 
which regulations are administered. Strict standards can and should promote resource productivity. The United States' regulatory process has squandered this potential, however, by concentrating on clean-up instead of prevention, mandating specific technologies, setting compliance deadlines that are unrealistically short and subjecting companies to unnecessarily high levels of uncertainty. However, regulation, according to Porter and van der Linde (1999), although a different type than as practiced, is needed for six major reasons:

1. To create pressure that motivates companies to innovate.

2. To improve environmental quality in cases in which innovation and the resulting improvements in resource productivity do not completely offset the cost of compliance; or in which it takes time for learning effects to reduce the overall cost of innovative solutions.

3. To alert and educate companies about likely resource inefficiencies and potential areas for technological improvement.

4. To raise the likelihood that product and process innovations in general will be environmentally friendly.

5. To create demand for environmental improvement until companies and customers are able to perceive and measure better the resource inefficiencies of pollution.

6. To level the playing field during the transition period to innovation-based environmental solutions, ensuring that one company cannot gain position by avoiding environmental investments. Regulation provides a buffer for innovative companies until new technologies are proven and the effects of learning can reduce technological costs.

\section{THE ENCOURAGEMENTS AND INCENTIVES FOR GREEN MANAGEMENT: PURPOSE OF GREEN MANAGEMENT}

Currently, in the United States, businesses can profit from two different avenues by implementing green management. The first avenue that businesses can profit by implementing green management is through claiming three different types of tax incentives: city, state, and federal. The second avenue is reputation branding, which, in turn, is the most powerful and effective marketing strategy. Businesses and consumers alike are seeking green management for two reasons (business and branding) that are inspired by the triplebottom line. To go green, companies have several voluntary avenues that can be taken, and in some cases going green can be required.

\section{Leadership in Energy and Environmental Design (LEED)}

The sole purpose of the USGBC is to transform the way buildings and communities are designed, built and operated, enabling an environmentally and socially responsible, healthy, and prosperous environment that improves the quality of life. USGBC utilizes the Leadership in Energy and Environmental Design (LEED) Green Building Rating System as a tool to accomplish its goal (U.S. Green Building Council, 2008). LEED is a voluntary, consensus-based national rating system for developing high-performance, sustainable buildings. Developed by USGBC, LEED addresses all building types and emphasizes state-of-the-art strategies for sustainable site development, water savings, energy efficiency, materials and resources selection, and indoor environmental quality. LEED is a practical rating tool for green building design and construction that provides immediate and measurable results for building owners and occupants.

LEED's green standards are determined by the United States Green Building Council (USGBC). The U.S. Green Building Council (USGBC) is a non-profit organization committed to expanding sustainable building practices (U.S. Green Building Council, 2008). USGBC is composed of more than 15,000 organizations from across the construction industry that are working to advance structures that are environmentally responsible, profitable, and healthy places to live and work. Members include building owners and end-users, real estate developers, facility managers, architects, designers, engineers, general contractors, subcontractors, product and building system manufacturers, government agencies, and non-profit organizations. 
Table 1. LEED

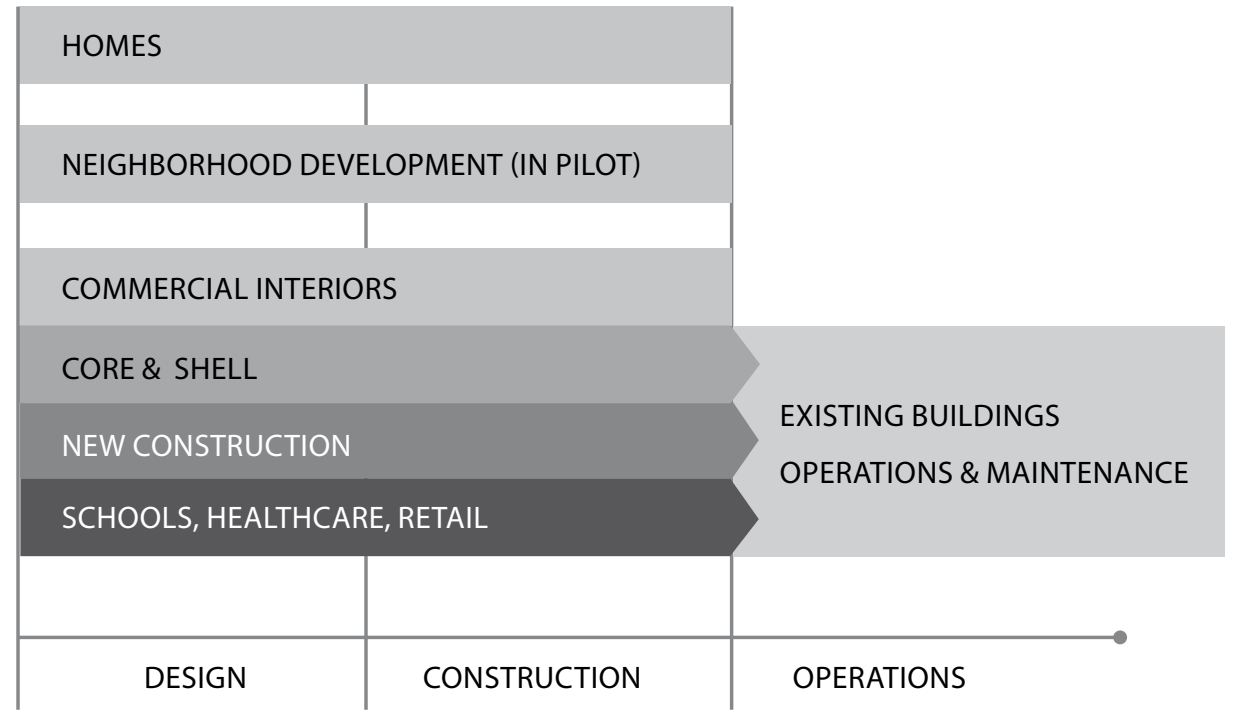

LEED is a third-party certification program and the nationally accepted benchmark for the design, construction and operation of high performance green buildings (Esty \& Winston, 2009; Makower, 2009; Stern \& Ander, 2008; Tefend, 2008)). LEED gives building owners and operators the tools they need to have an immediate and measurable impact on their buildings' performance. LEED promotes a whole-building approach to sustainability by recognizing performance in five key areas of human and environmental health: sustainable site development, water savings, energy efficiency, materials selection, and indoor environmental quality (see Table 1).

\section{THE PURPOSE OF GREEN MANAGEMENT: VOLUNTARY COMPLIANCE AND REQUIRED IMPLEMENTATION}

\section{Voluntary Compliance (Cradle-To-Cradle)}

Cradle-To-Cradle (C2C) is a term coined by Walter $\mathrm{R}$. Stahel ${ }^{26}$ in the 1970 s, initiated by Michael Braungart

26 Walter R. Stahel is a graduate of ETH, the Swiss Federal Institute of Technology, in Zürich, where he received his diploma in architecture in 1971. He has joined the Geneva Association (International Association for the Study of Insurance Economics) in in the 1990s, and explored and popularized by William McDonough in 2002 through his published article titled Cradle to Cradle: Remaking the Way We Make Things. Cradle-to-Cradle Design (sometimes abbreviated as $\mathrm{C} 2 \mathrm{C}$ or in some circles referred to as regenerative) is a bio-mimetic approach to the design of systems. It models human industry on Nature's processes, in which materials are viewed as nutrients circulating in healthy, safe metabolisms. It suggests that industries must protect and enrich ecosystems, nature's biological metabolism, while also maintaining safe, productive technical metabolism for the high-quality use and circulation of organic, synthetic, and other materials. Put simply, it is a holistic economic, industrial and social framework that seeks to create systems that are not just efficient, but are essentially waste free (Lovins, 2008). The model in its broadest sense is not limited to industry. It can be applied to many different aspects

1987 , as director in charge of risk management research. He is also one of the founder-directors of the Product-Life Institute (since 1983). Before that, Stahel worked as an architect in London and as a project-manager at the Battelle Geneva Research Centers, Geneva, for Applied Economics, in the fields of business strategy and feasibility studies. He left Battelle in 1980 to become personal assistant to the CEO of a holding company with worldwide activities in railway maintenance, shipping, and real estate. Since 1984, Stahel has worked as a business consultant in most European countries, the U.S., and Far Eastern countries. 
of human civilization, including urban environments, buildings, industrial design and manufacturing, economics, and social systems.

In the Cradle-to-Cradle model, green materials used in industrial or commercial processes (such as metals, fibers, dyes, etc.) are seen to fall into one of two categories: technical or biological nutrients. Technical nutrients are strictly limited to non-toxic, non-harmful synthetic materials that have no negative effects on the natural environment, and they can be used in continuous cycles as the same product without losing their integrity or quality. For example, these materials can be used over and over again in many variations, instead of being down-cycled into lesser products, ultimately becoming waste. Biological Nutrients are organic materials that, once used, can be thrown onto the ground, on the garden, in a river or any natural environment, and decompose into the soil providing food for small life forms, without affecting the natural environment (McDonough \& Braungart, 2002).

In 1995, McDonough and Braungart founded the McDonough Braungart Design Chemistry (MBDC) consulting and then established the $\mathrm{C} 2 \mathrm{C}$ certification program (Appendix A) ${ }^{27}$. The MBDC's C2C Design paradigm is powering the Next Industrial Revolution, in which products and services are designed based on patterns found in nature, eliminating the concept of waste entirely and creating an abundance that is healthy and sustainable (MBDC, 2009a). MBDC offers clients a variety of services to industries of all types and sizes. These include C2C Design project consulting using the Protocol for creating healthy products and processes, $\mathrm{C} 2 \mathrm{C}$ education and training, and corporate environmental strategies consulting. Currently, MBDC is also developing tools to assist companies and designers in creating ecologically intelligent products and services (MBDC, 2009b).

\section{Required Implementation}

The degrees to which businesses are required to implement green management rest upon the financial scope

27 For an example of LEED for Home rating system, please refer to LEED for Homes Program Pilot Rating System, available at $<$ http://www.usgbc.org/ShowFile.aspx?DocumentID=2267>. of the changes. More and more cities are now requiring green management practices in new construction. Changes below a certain financial standards set forth by the city in the commercial zone of the business location are not required to adapt green management practices. For example, on June 2, 2008, the Palo Alto City Council adopted a mandatory Green Building Ordinance which became effective on July 2, 2008, and it is applicable to residential and non-residential private development projects. The ordinance was retroactive for commercial projects for which planning applications were submitted after December 3, 2007, the date the City Council adopted the Climate Protection Plan describing intended green building standards (City of Palo Alto, 2008). The city of Palo Alto, home of Stanford University, in the State of California is one of a growing numbers of cities that require all business buildings to go green. The degrees of the green management adaptation are clearly outlined (Appendix B).

\section{WHAT ARE THE ENCOURAGING AND INCENTIVES FOR GREEN MANAGEMENT?}

LEED certified buildings use key resources more efficiently when compared to conventional buildings simply built to code. LEED certified buildings are healthier work and living environments, which contribute to higher productivity and improved employee health and comfort. Nevertheless, the USGBC has also compiled a long list of benefits of implementing a LEED strategy that ranges from improving air and water quality to reducing solid waste. The fundamental reduction in environmental impacts, in addition to all of the economic and occupant benefits, goes a long way for making a case for green building. It is also important to note that these benefits are obtained by anyone who come into contact with the project, including owners, occupants, and society as a whole.

\section{Tax Incentives}

Tax benefits do not come without a cost, however. According to Tefend (2008), green buildings cost more both to design and to construct when compared to conventional buildings. The cost of designing a LEED certified building is higher for several reasons. One 
reason is greater set-up costs and lack of short term gain in life cycle costing. Some of the finer points of LEED certification (especially those that demand a higher-than-orthodox standard of service from the construction team) could possibly lead to misunderstandings between the design team, the construction team, and the client, which could result in delays. Also, there may be a lack of abundant availability of manufactured building components that would meet LEED standards. Pursuing LEED certification for a project is an added cost in itself as well. This added cost comes in the form of USGBC correspondence, LEED design-aide consultants, and the hiring of the required Commissioning Authority (CxA), all of which would not necessarily be included in an environmentally responsible project, unless it was also seeking LEED certification.

Often, when LEED certification is pursued, the initial construction cost of the project will be higher than the current non-LEED industry standard. However, these initial high costs can be effectively mitigated by the savings incurred over time due to the lower-thanindustry-standard operational costs, which are typical of any LEED certified building. Additionally, economic payback may come in the form of employee productivity gains incurred as a result of working in a healthier environment. Studies have suggested that an initial upfront investment of $2 \%$ extra will yield over ten times the initial investment over the life cycle of the building (Kats, Alevantis, Berman, Mills, \& Perlman, 2003).

Although the deployment of the LEED Standard has raised awareness of Green Building practices, its scoring system is skewed toward the ongoing use of fossil fuels. More than half of the available points in the Standard support efficient use of fossil fuels, while only a handful are awarded for the use of sustainable energy sources. Further, the USGBC has stated support for the 2030 Challenge, an effort that has set a goal of using no fossil-fuel green-house-gas-emitting energy to operate by 2030 . In addition to focusing on efficient use of fossil fuels, LEED focuses on the end product. For example, because leather does not emit Volatile Organic Compounds (VOC), it is deemed healthy for environments, disregarding the use of extremely harmful chemicals in the process of tanning leather.
Other products that do not use harmful chemicals and focus on more sustainable production do not earn any additional points for their attention to environmental concerns (Appendix C).

\section{METHODOLOGY}

\section{Participants}

The participants in this study had two components. The first component of the participant was a licensed architect who was a practitioner with more than seventeen years of experiences in both commercial and residential industries. The architect graduated with a Master of Architecture (M.Arch.) from the Georgia Institute of Technology and is licensed by the State of California. The second component was based on case studies of corporate giants like Google, VMware and Sony.

The reasons why only one licensed active architect was interviewed among other numerous architects available are based on a few factors. First, not all architects nor architectural firms are certified as green architect or green architectural management. Second, not all architects requested to participate accepted the invitation, since participation was voluntary. Third, those who accepted the invitation were not necessarily involved in green architectural projects nor had access to information related to green architectural projects. Thus, only one licensed active architect was interviewed because he complied with all the conditions: voluntary participation, and had access to green architectural information and green architectural related information.

Case studies of Google, VMware, and Sony on green management were used. Two of the three businesses (Google and Sony) were not only international businesses, but well-known, well-established, household names. Meanwhile, VMware is well-known in the hightech industry. Along with these organizations, there are many other businesses that have gone green, but their reputations and histories are limited to the United States of America. Thus, Google, VMware, and Sony were selected as case studies on green management. On that note, the architect interviewed was aware of 
information based on informal and formal networks among architects and its industry.

\section{Material}

Materials utilized in this study consisted of two types. The first was the informal unstructured interview and the second was the LEED certification. The informal unstructured interview was utilized as a reference point (exporter/expertise) to the ins-and-outs of the green management process and the reasons for a lack of green management. The LEED certification was utilized to better understand the degree of greenness participants have undertaken, and the benefits derived, if any.

\section{Procedures}

The informal unstructured interview with the licensed architect was a continuous process (before, during, and after) of this study. The architect provided information pertaining to the practice of green management, the process and the procedures of green management, and the regulations and the policies of green management in certain localities within the State of California. Interviews with the architect on green management are approximately an hour each and case studies of Google, VMware, and Sony are certified public information and knowledge required by law in the State of California.

Certified public information and knowledge on green management in regards to these case studies were not interpreted nor analyzed with the assistance of the architect. Interviews with the architect on the certified public information and knowledge gained through the analyses of these case studies regarding green management were conducted to assist on the clarifications of and to address the scarcity that exists pertaining to the analyses of such information. Knowledge and expertise of the architect on green management were obtained through experiences as a licensed active architect in the industry, as well as information and knowledge publicly and commonly shared and exchanged among architectural practitioners in the industry. No private and no confidential information nor knowledge were exchanged nor bestowed to this study from the architect that is not already available to the public.

\section{DISCUSSION}

While businesses are all ears on the green management concept, the commitment to become one of the few leading innovative leaders on the green management band-wagon has yet to become mainstream. Thus, statistically, quantitative data lacks strong validity for it is not representative. Qualitative data, on the other hand, is often premature, for businesses have yet to witness the full advantages and benefit from the profits that green management has to offer. This is because implementing green management can be viewed as a race. Benefiting from green management, however, is more of a marathon than a race. Nevertheless, of the trend or a lack thereof, some of the more well-known industry giants who are the forefront innovative leaders implementing green management are Google, VMware, and Sony.

\section{Google}

Google's (2008a) mission is to organize the world's information and make it universally accessible and useful. As a first step to fulfilling that mission, Google's founders Larry Page and Sergey Brin developed a new approach to online search practices that took root in a Stanford University dorm room and quickly spread to information seekers around the globe. Google is now widely recognized as the world's largest search engine -an easy-to-use free service that usually returns relevant results in a fraction of a second. With that said, Googol is the mathematical term for a one followed by one hundred zeros. The term was coined by Milton Sirotta, nephew of an American mathematician Edward Kasner, and was popularized in the book, Mathematics and the Imagination by Edward Kasner and James Newman. Google's play on the term reflects the company's mission to organize the immense amount of information available on the web.

The tagline for Google's commitment to implementing green management is At Google, we're committed to helping build a clean energy future, and launched their Renewable Energy Cheaper Than Coal $(\mathrm{RE}<\mathrm{C})$ project. $\mathrm{RE}<\mathrm{C}$ is a strategic initiative whose mission is to develop electricity from renewable sources cheaper than electricity produced from coal. Initially, this project to 
create renewable energy cheaper than coal will focus on advanced solar thermal power, wind power technologies, and enhanced geothermal systems - but Google will explore other potential breakthrough technologies too. In so doing, according to Google (2008b), the corporation is busy assembling their own internal research and development group and hiring a team of engineers and energy experts tasked with building one gigawatt of renewable energy capacity that is cheaper than coal (that is enough electricity to power a city the size of San Francisco). Google's Research and Development (R\&D) effort will begin with a significant effort on solar thermal technology, and will also investigate enhanced geothermal systems, and other areas.

Google's team of engineers and energy experts are from many sources including the following: (a) BrightSource Energy, Inc., which designs and builds large scale solar plants that deliver low-cost solar energy in the form of steam and/or electricity at prices competitive with fossil fuels for industrial and utility customers worldwide; (b) eSolar, Inc., which specializes in solar thermal power technology that replaces the fuel in a traditional power plant with heat produced from solar energy, and has great potential to produce utility-scale power that is cheaper than coal; (c) Makani Power, Inc., which is developing high-altitude wind energy extraction technologies aimed at harnessing the world's most powerful wind resources which capturing just a fraction of available high-energy wind would be sufficient to supply current global electricity needs; (d) AltaRock Energy, Inc., which develops innovative technologies to achieve significant cost reductions and improved performance in EGS projects; and (e) Potter Drilling, Inc., which develops new approaches to lower the cost and expand the range of deep hard rock drilling, a critical element to large-scale deployment of EGS. This current initiative is just the next step in Google's continuing commitment to a clean and green energy future. Google has been working hard on energy efficiency and making their business environmentally sustainable.

Google has taken concrete steps to reduce their carbon footprint and accelerate improvements in green technology. For example, through design improvements and the adoption of power-saving technologies (such as evaporative cooling), Google has made great strides to bolster the efficiency of their data centers (the facilities that store the computers that enable Google to deliver accurate search results at lightning speed). Google has also reduced the carbon footprint of their building and office operations, for example, by replacing incandescent bulbs with higher-efficiency lighting, and maximizing the use of natural light. Even more impressive, earlier this year Google flipped the switch at their Mountain View, California headquarters on one of the largest corporate solar panel installations in the United States.

\section{VMware}

VMware, Inc. (2008a) is the global leader in virtualization solutions from the desktop to the data center. Customers of all sizes rely on VMware to reduce capital and operating expenses, ensure business continuity, strengthen security, and to go green. With 2007 revenues of $\$ 1.33$ billion, more than 120,000 customers and more than 20,000 partners, VMware is one of the fastest-growing public software companies. Headquartered in Palo Alto, California, VMware is majorityowned by EMC Corporation (or EMC ${ }^{2}$ ). With that said, the company was founded in 1998 and the name VMware comes from the acronym " $\mathrm{VM}$," meaning virtual machine, while "ware" comes from the second part of software.

Diane Greene, Mendel Rosenblum, Scott Devine, Edward Wang, and Edouard Bugnion founded VMware in 1998 (VMware, 2008b). Ms. Greene earned a Master's Degree in Naval Architecture from Massachusetts Institute of Technology (MIT) in 1978, and in 1988 she earned a second Master's Degree in Computer Science from the University of California at Berkeley (Lashinsky, 2007). Rosenblum and Greene, who are married, first met while at Stanford. Edouard Bugnion remained the Chief Architect and Chief Technology Officer (CTO) of VMware until 2005 (Baldwin, 2004), and went on to found Nuova Systems (now part of Cisco).

The first release, VMware workstation, was launched in 1994. In 2001, the company introduced its first server products, VMware GSX (hosted) and VMware ESX (hostless). Virtual Center, Vmotion and Virtual SMP were 
introduced in 2003, and the 64-bit support appeared in 2004. The company was also acquired by EMC Corporation that same year.

VMware (2008c) believes that open standards and industry collaboration are essential to creating impactful solutions and promoting energy efficiency. To this end, VMware is a founding member of The Green Grid, a global consortium dedicated to advancing energy efficiency in datacenters and business computing ecosystems. In furtherance of its mission, The Green Grid is focused on the following: (a) defining meaningful, user-centric models and metrics; (b) developing standards; measurement methods, processes and new technologies to improve data center performance against the defined metrics; and (c) promoting the adoption of energy efficient standards, processes, measurements and technologies. Comprised of an interactive body of members who share and improve current best practices around data center efficiency, The Green Grid's scope includes collaboration with end users and government organizations worldwide to ensure that each organizational goal is aligned with both developers and users of data center technology. Members include vendors such as Advanced Micro Devices (AMD), American Power Conversion (APC), Cisco, Dell, Emerson, Fujitsu, Fujitsu Siemens, Hewlett-Packard (HP), International Business Machine (IBM), Intel, Microsoft, and Sun, and end users such as Automatic Data Processing, Inc. (ADP), Allstate, BT, Enterprise, Facebook, and Fed Ex Services.

\section{Sony}

Sony Corporation of America (2008), based in New York, NY, is a U.S. subsidiary of Sony Corporation, headquartered in Tokyo. Sony is a leading manufacturer of audio, video, communications and information technology products for the consumer and professional markets. Its motion picture, television, computer entertainment, music, and online businesses make Sony one of the most comprehensive entertainment companies in the world. Sony's principal U.S. businesses include Sony Electronics Inc., Sony Pictures Entertainment Inc., Sony Computer Entertainment America Inc., and Sony BMG Music Entertainment, one of the largest recorded music companies in the world. Sony recorded consolidated annual sales of approximately $\$ 88.7$ billion for the fiscal year ended March 31, 2008, and it employs 180,500 people worldwide. Sony's consolidated sales in the U.S. for the fiscal year ended March 31, 2008 were $\$ 29$ billion.

Sony has established Green Management 2010 (Sony, 2008), a new mid-term group of environmental targets that will succeed Green Management 2005, and run through fiscal 2010. The targets will guide the Sony Group in its efforts to help prevent global warming, recycle resources, ensure appropriate management of chemical substances, and address a broad range of other complex environmental issues.

\section{- Establishing Green Management 2010}

Since the 1990s, Sony focused on a variety of activities, such as developing environmentally conscious products, reducing the environmental impact of its sites, and promoting product recycling. In 1998, Sony formulated its first set of mid-term environmental targets, which has undergone subsequent annual revisions. Most recently, in 2006 Sony launched Green Management 2010, new mid-term targets outlining the challenges facing the Sony Group between now and fiscal 2010. When setting targets for Green Management 2010, Sony gave full consideration to the conclusions drawn from its review of Green Management 2005 as well as to legislative trends that could affect the Sony Group in the medium to long term.

Consideration was also given to the concerns of investors, environmental nongovernmental organizations (NGOs), and other stakeholders regarding Sony and the direction of its business over the next 5 years. As a part of these activities, Sony exchanged opinions with several environmental NGOs, according to specific themes such as prevention of global warming, and natural environmental conservation. Sony also had three basic goals in mind when setting the targets, which were to aim high as a cutting-edge, global corporation, set targets for reductions of absolute greenhouse gas emissions and other sources of environmental impact, and create global challenges for the entire Sony Group (see Figure 1). 


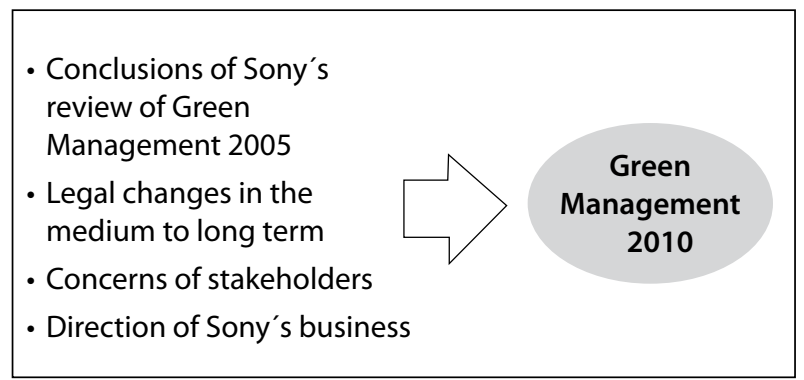

Figure 1. Establishing Green Management 2010

- Targets of Green management 2010

Green Management 2010 encompasses general indicators, as well as individual targets. The general indicators, comprised of greenhouse gas and resource indices, are set to determine the environmental impact of the total life cycle of the Sony Group's business activities, products and services, to the maximum possible extent. The indicators are also used to monitor Sony's performance of the individual targets set to reduce environmental impact throughout the business cycle. The various elements of each of these indices were chosen based on such criteria as seriousness of environmental impact and controllability. Sony will continue to monitor eco-efficiency and evaluate the progress of environmental efforts and use the results to revise its various initiatives and targets (see Table 2).
Green Management 2010's individual targets cover Sony's entire business cycle, from the procurement of parts to the manufacturing, use, disposal and recycling of products. For example, to contribute to the prevention of global warming, targets have been set for absolute reductions in greenhouse gas emissions at Sony Group sites throughout the world. At the same time, by including targets for controlling operating power consumption, as well as for ascertaining and reducing energy consumption during transport, Sony aims to gradually reduce the environmental impact of manufacturing, transporting and using Sony products. Green Management 2010 also outlines a broad range of other targets pertaining to, among others, communicating effectively with Sony's diverse stakeholders about environmental issues, promoting partnerships with other companies and encouraging education on the subject of conservation.

\section{LIMITATIONS OF THE STUDY}

While businesses are all ears on the green management concept, the commitment to become one of the few leading innovative leaders on the green management band-wagon has yet to become mainstream. Thus, there are three limitations inherent in this green management analyses. First, statistically, quantitative data lacks strong validity for it is not representative.

Table 2. Green Management 2010 General Indicators Calculation

Green Management 2010 General Indicators Calculation

\begin{tabular}{ll}
\hline Indicator Calculation \\
\hline
\end{tabular}

Greenhouse gas index Total greenhouse gas emissions from sites (calculated in terms of CO2) + Total CO2 emissions from product use + Total CO2 emissions from logistics - Greenhouse gas emissions offset by greenhouse gas reduction activities

Resource index Waste land filled from sites + Product resource input ${ }^{* 1}$ - Volume of reused/recycled materials ${ }^{* 2}$ Volume of resource recovery from end-of-life products

*1 Defined as the volume of resources used in products, accessories, manuals and packaging, less the volume of waste resources from the Sony Group that are reused/recycled

*2 Defined as the volume of materials reused or recycled back into products 
Qualitative data, on the other hand, is quite premature, for businesses have yet to witness the full advantages and benefit from the profits that green management has to offer. This is because implementing green management can be viewed as a race, however benefiting from green management is more of a marathon than a race.

Second, LEED, developed by USGBC, is a voluntary process established upon a consensus-based national rating system for developing high-performance, sustainable buildings. In other words, potential clients of LEED are architects, real estate professionals, facility managers, engineers, interior designers, landscape architects, construction managers, lenders, and government officials who need help in transforming the built environment to sustainability. State and local governments across the country are adopting LEED for public-owned and public-funded buildings. There are LEED initiatives in federal agencies, including the Departments of Defense, Agriculture, Energy, and State. With that said, LEED projects are in progress in forty-one different countries, including Canada, Brazil, Mexico, and India.

Nevertheless, LEED itself is a voluntary process, which translates to not required by the law. Businesses who are not persuaded by the added value due to the level of standards (silver, gold, and platinum) certified by the LEED or to be green are not motivated to voluntary participate. Thus, using the LEED certification as an instrument of measurement would yield data, but data that will commit the first limitation mentioned.

Third, green management as a concept in practice is encountering similar dilemma that green vehicles as a practical concept is encountering. Both are innovative and green, the rewards are not instantly apparent, and the non-green suppliers (oil companies for vehicles for an example) are not ready to share their profits. While going green is inevitable, the mentality on turning green is another issue. Nevertheless, politics of profits come into play, and the judge of them is our government. Future mandates by our government will determine the outcome of the second limitation of this study, in turn, will influence the third limitation of this study and green management analyses in gen- eral. As noted earlier, there are local municipalities that are beginning to require green management practices similar to those prescribed in LEED.

\section{CONCLUSION}

Green management is not the repackaging, the reinventing approaches to business, nor business management. Green management is not a concept describing new business management style. Green management is simply the rethinking, or more accurately, being more mindful of how organizations are operating (or a lack thereof) with respect to the environment. It is not the human factors within the organization that are being managed but the components of the organization that are being managed by green management. From the business management perspective, green management matters, but it matters only due to the so called triple bottom line.

As stated above, the triple bottom line consists of environmental benefits, positive economics effect, and healthy societal images. Contributing to the triple bottom line and supporters of the green management are tax incentives (city, state, and federal) backed by LEED. Many businesses have gone green or in the process of going green. Among them are the more internationally known Google, VMware, and Sony. Nevertheless, the voluntary process of going green up to date is governed by LEED.

The present analysis of green management addresses a scarcity that currently exists in the academic literature. The perspective of practitioners on green management was analyzed, as well as its main focus. Specifically, there are two central concerns: (a) what are the encouragements and incentives for green management; and (b) what are some of the concerns, confusions, and barriers to green management.

Green management and going green are not as clear cut and easy as hyped by the general media. While going green is indeed beneficial and appropriate, the process and procedure of going green, is anything but easy. First, going green is largely not a legal requirement, but a voluntary process. Thus, 
even though LEED (which is by far the more publicly known green certification standard) governs the certification of the green management effort, it is not a legal requirement for practitioners. Second, even with the encouragement of incentives to go green, practitioners are skeptical in doing so due to: (a) a lack of true understanding of the benefit of going green (the practice of profits versus the theory of benefits); (b) a lack of short term gain in life cycle costing (practitioners want instant incentives); and, (c) it is not a legal requirement for the vast majority of municipalities. So, the common philosophy that tends to prompt inactivity and unresponsiveness is "if it ain't broken, don't fix it."

\section{REFERENCES}

City of Palo Alto. (2008). City of Palo Alto: New green building requirements adopted. Retrieved on November 27, 2008, from <http://www.cityof paloalto.org/news/ displaynews.asp?NewsID=1007\&Target ID=205>.

Baden, S., Waide, P., Fairey, P., \& Laustsen, J. (2006). Hurdling financial barriers to low energy buildings: Experiences from the usa and europe on financial incentives and monetizing building energy savings in private investment decisions. Proceeding of 2006 ACEEE Summer Study on Energy Efficiency in Buildings, American Council for an Energy Efficient Economy, Washington, DC., August 2006. Retrieved on October 8, 2008, from <http://www.fsec.ucf.edu/en/publications/pdf/ FSEC-PF-396-06.pdf $>$.

Baldwin, H. (2004). Edouard Bugnion lives in the virtual world: VMware's chief architect is turning his attention from virtual servers to virtual storage. InfoWorld. Retrieved on November 19, 2008, from < http://www. inforworld.com/article/04/01/23/04FEctoedouard 1.html?s=feature $>$.

Boroughs, D. L., \& Carpenter, B. (1991). Helping the planet and the economy. U.S. News and World Report, 110, 46.

Citizen Decca (N.Y.). What does it mean to be green? Retrieved on October 9, 2008, from <http://www.deccacontract.com/download/What\%20Does\%20lt\%20 Mean\%20To\%20Be\%20Green.pdf>.

Dorfman, M. H., Muir, W. R., \& Miller, C. G. (1992). Environmental dividends: Cutting more chemical wastes. New York: INFORM.

Elkington, J. (1994). Towards the sustainable corporation: Win-win-win business strategies for sustainable development. California Management Review, 36(2), 90-100.

Esty, D. C. \& Winston, A. S. (2009). Green to gold: How smart companies use environment strategy to innovate, create value, and build competitive advantage. Hoboken, NJ: John Wiley \& Sons, Inc.

Frej, A. (2005). Green office buildings: A practical guide to development. Washington, D.C.: ULI-The Urban Land Institute.

Google. (2008a). Company overview. Retrieved on November 19, 2008, from <http://www.google.com/corporate/ index.html>.

Google. (2008b). Powering a clean energy revolution. Retrieved on November 19, 2008, from <http://www.google. com/corporate/green/energy/index.html>.

Hopkins, R. (2002). A natural way of building. In Lumpy L. Transition culture: An evolving exploration into the head, heart and hands of energy descent. Retrieved on September 25, 2008, from <http://transitionculture. org/essential-info/articles/a-natural-way-ofbuilding-2002/>.

Kats, G., Alevantis, L., Bermna, A., Mills, E., \& Perlman, J. (2003). The costs and financial benefits of green buildings: $A$ report to California's sustainable building task force. Retrieved on November 20, 2008, from <http://www. cap-e.com/ewebeditpro/items/ O59F3259.pdf>.

King, A. (1994). Improved manufacturing resulting from learning from waste: causes, importance, and enabling conditions. New York: New York University, Stern School of Business.

Kleiner, A. (1991). What does it mean to be green? Harvard Business Review, July-August, 1-9.

Lange, J., Grottker, M., \& Otterpohl, R. (1998). Sustainable water and waste management in urban areas. Water Science and Technology, 35(9), 121-133.

Lashinsky, A. (2007). Full speed ahead. Fortune Magazine. Retrieved on November 19, 2008, from <http:// 
money.cnn.com/magazines/fortune/fortune_ archive/2007/10/15/100536853/>.

Levin, H. (2008). Ten basic concepts for architects and other building designer: Best sustainable indoor air quality practices in commercial buildings. Hal Levin \& Associates, Santa Cruz, CA. Retrieved on October 8, 2008, from <http:// www.buildinggreen.com/elists/halpaper.cfm $>$.

Lovins, L. H. (2008). Rethinking production. The Worldwatch Institute, State of the world: Innovations for a sustainable economy (32-44). Retrieved on November 18, 2008, from <http://www.worldwatch.org/files/pdf/ SOW08_chapter_3.pdf $>$.

MBDC. (2009a). Executive overview: Cradle to cradle design. Retrieved on March 1, 2009, from <http://www.mbdc. com/overview.htm>.

MBDC. (2009b). Executive overview: Products and services. Retrieved on March 1, 2009, from <http://www.mbdc. com/overview.htm>.

McDonough, W., \& Braungart, M. (2002). Cradle to cradle: Remaking the way we make things. New York: North Point Press Publisher.

Makower, J. (2009). Strategies for the green economy: Opportunities and challenges in the new world of business. New York: McGraw-Hill Publishers.

Porter, M. E., \& van der Linde, C. (1999). Green and competitive: Ending the stalemate. Journal of Business Administration and Policies, 215. Retrieved on March 1, 2009 from <http://www.ww.uni-magdeburg.de/bwl2/Lehre/ L-Puppim/Porter_vdLinde.pdf $>$.

Sheridan, J. H. (1992, February 17). Attacking wastes and saving money...some of the time. Industry Week, 43.

Simpson, J. R. (2002). Improved estimates of tree-shade effects on residential energy use. Energy and Building, 34(30), 1067-1076.

Sony Corporation of America. (2008). Corporate social responsibility: Environment management. Retrieved on November 19, 2008, from <http://www.sony.net/ Sonylnfo/Environmental/activities/management/ gm2010/index.html>.

Sony Corporation of America. (2008). Overview. Retrieved on November 19, 2008, from <http://www.sony.com/ SCA/index.html>.
Stern, N. Z., \& Ander, W. N. (2008). Greentailing and other revolutions in retail: Hot ideas that are grabbing customers attention and raising profits. Hoboken, NJ: John Wiley \& Sons, Inc.

The Dictionary of Sustainable Management. (N.Y.). Triple bottom line. Retrieved on March 1, 2009, from <http:// www.sustainabilitydictionary.com/t/triple_bottom_ line.php>.

The Green Grid. (2008). About us: Overview. Retrieved on November 19, 2008, from <http://www.thegreengrid. org/about/overview/>.

U.S. Department of Energy (2007). Energy consumption by sector. Energy Information Administration, Washington, DC. Retrieved on October 8, 2008, from <http://www. eia.doe.gov/emeu/aer/pdf/pages/sec2.pdf>.

U.S. Department of Energy (2008). Annual energy review 2007. Energy Information Administration, Washington, DC. Retrieved on October 8, 2008, from <http://www.eia. doe.gov/emeu/aer/pdf/aer.pdf>.

U.S. Environmental Protection Agency Green Building Workgroup (2004). Buildings and the environment: A statistical summary. U.S. Environmental Protection Agency Green Building Workgroup. Retrieved on October 8, 2008, from <http://www.epa.gov/greenbuilding/pubs/ gbstats.pdf $>$.

U.S. Green Building Council. (2008). About us gbc. Retrieved on November 19, 2008, from <http://www.usgbc. org/DisplayPage.aspx?CMSPagelD=124>.

VMware. (2008a). About VMware. Retrieved on November 19, 2008, from <http://www.vmware.com/company/>.

VMware. (2008b).VMware Leadership. Retrieved on November 19, 2008, from <http://www.vmware.com/company/ leadership.html>.

VMware. (2008b). Get connected to efficient with the green grid. Retrieved on November 19, 2008, from <http:// www.vmware.com/solutions/greenlT/greengrid. html>.

World Business Council for Sustainable Development (2008). Energy efficiency in buildings: Business realities and opportunities. Retrieved on October 8, 2008, from $<$ http://en.wikipedia.org/wiki/Green_building>. 


\section{Appendix A \\ Example of LEED Rating System}

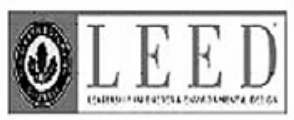

LEEO.CS Verslon 2.0 Reglstered Project Chrockillst

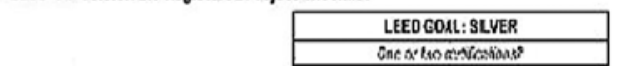

\begin{tabular}{|c|c|c|c|c|c|c|c|c|c|c|c|}
\hline$n$ & $1 \%$ & min & am, & $\pi$ & \multicolumn{2}{|c|}{ 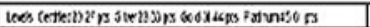 } & & & & & \\
\hline$n$ & 2 & $n$ & 5 & 11 & \multicolumn{7}{|c|}{ 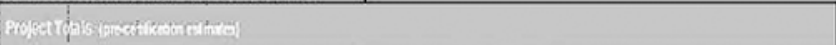 } \\
\hline ต & i & 1 & 2 & & \multicolumn{2}{|c|}{ suspinsliesilces. } & $15 \mathrm{~min}$ & twh & $\operatorname{lng}_{\operatorname{lng}}$ & $\sin x$ & somenuterawe \\
\hline y & & & & & naw & 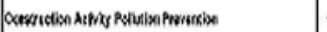 & сура: & & & & \\
\hline 1 & & & & & $\operatorname{sen}$ & sia samean & : & & & & \\
\hline 1 & & & & & ene.2 & 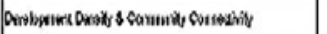 & ' & & & & \\
\hline 1 & & & & & $6 r \pm 3$ & Errantiod hodaciognent & 1 & & & & \\
\hline 1 & & & & & $6 * \pm+1$ & 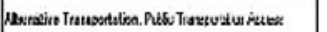 & : & & & & \\
\hline 1 & & & & & $c x \neq i 2$ & 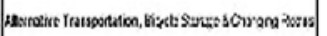 & 1 & & & & \\
\hline 1 & & & & & $(x ; i)$ & 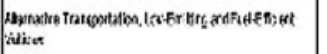 & ' & & & & \\
\hline 1 & & & & & $\Leftrightarrow \rightarrow+4$ & 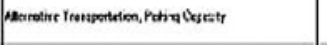 & , & , & & & 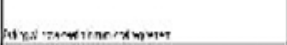 \\
\hline & & & 1 & & ovะ.,1: & 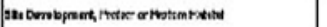 & ' & & & & \\
\hline & & & : & & $c x: 52$ & 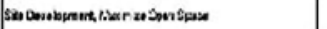 & 1 & & & & \\
\hline & & & , & & $\sin x$ & 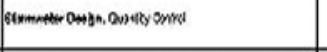 & : & & & & 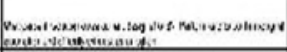 \\
\hline 1 & & & & & cos:s: & stmmator Deagn, Cua by carris & $t$ & & & & 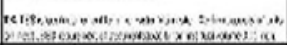 \\
\hline 1 & & & & & cus.s. & Hest ilano Etice, Nomist & 1 & . & & & 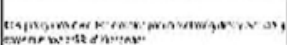 \\
\hline
\end{tabular}




\section{Appendix B \\ City of Palo Alto \\ Green Building Standards for Compliance for Private Development Nonresidential Construction and Renovation*}

\begin{tabular}{|c|c|c|c|}
\hline \multirow{2}{*}{ Type of Project ${ }^{5}$} & \multicolumn{3}{|c|}{ Building Improvements } \\
\hline & Checklist Required $^{2}$ & Minimum Threshold & Verification \\
\hline \multicolumn{4}{|c|}{ Nonresidential Construction and Renovation ${ }^{1}$} \\
\hline New construction $\geq 25,000 \mathrm{sf}$ & LEED-NC Checklist & LEED Silver (33 points) & LEED/USGBC verification \\
\hline $\begin{array}{l}\text { New construction } \geq 5,000 \text { sf and } \\
<25,000 \mathrm{sf}\end{array}$ & LEED-NC Checklist & LEED Silver (33 points) & Threshold verification by LEED AP \\
\hline $\begin{array}{l}\text { New construction } \geq 500 \text { sf and }< \\
5,000 \text { sf }\end{array}$ & LEED-NC Checklist & LEED Pro-rated points ${ }^{3}$ & Threshold verification by LEED AP \\
\hline $\begin{array}{l}\text { Renovation } \geq 5,000 \text { sf and }>50 \% \\
\text { of building sf and }>\$ 500,000^{6} \\
\text { valuation }\end{array}$ & LEED-NC Checklist & LEED Certified (26 points) & Threshold verification by LEED AP \\
\hline $\begin{array}{l}\text { Other renovation } \geq \$ 100,000^{6} \\
\text { valuation }\end{array}$ & LEED-CI Checklist & $\begin{array}{l}\text { Submit checklist; include } \\
\text { on building plans }\end{array}$ & Self verification \\
\hline
\end{tabular}

New construction $<500 \mathrm{sf}$

and renovation $<\$ 100,000^{6} \quad$ No requirement

of valuation

Mixed Use or Other $\quad$ Commercial and residential criteria as applicable
Development

* Adopted from http://www.cityofpaloalto.org/civica/filebank/blobdload.asp?BlobID=12193

1. Cumulative new construction or renovations over any 2-year period following adoption of these requirements shall be considered as a single project, unless exempted by the Planning Director as impractical for compliance.

2. Compliance with other LEED ${ }^{\circledR}$ checklists, including but not limited to LEED-CS (Core \& Shell), LEED-Cl (Commercial Interiors), or LEED-EB (Existing Buildings) may be substituted for the designated rating system where deemed appropriate by the Planning Director, after recommendation by the Architectural Review Board (if ARB review is required).

3. Pro-rated formula $=($ new construction $s f / 5,000) \times 33$ points, but not less than 17 points.

4. To be determined by the Planning Director; generally the provisions of Table A will apply to the commercial portion of the development, and the provisions of Table B will apply to the residential portions of the development.

5. Exemptions and incentives may be available for historic structures, pursuant to Section 18.44 .070 of the ordinance. The Compliance Official may allow the use of alternative checklists for historic buildings or for buildings that retain or re-use substantial portions of the existing structure.

6. To be adjusted annually to reflect changes to the City's valuation per square foot of new construction. 


\section{Appendix C \\ Point Rating}

Points have been distributed as follows. Required "prere-quisites" in each category receive no points.

\section{Sustainable sites (14 points)}

- Construction Activity Pollution Prevention Plan (required)

- Site selection (1 pt)

- Development density and community connectivity (1 pt)

- Brownfield redevelopment (1 pt)

- Alternative transportation availability (3 pts)

o Public transportation access (1 pt)

o Bicycle storage and changing rooms (1 pt)

o Parking capacity and carpooling (1 pt)

- Reduced site disturbance (2 pt)

o Protect or restore open space (1 pt)

o Development footprint

- Stormwater management (2 pts)

o Rate and quantity (1 pt)

o Treatment (1 pt)

- Reduce heat islands (2 pts)

o Roof (1 pt)

o Non-roof (1 pt)

- Light pollution reduction (1 pt)

\section{Water efficiency (5 points)}

- Water efficient landscaping (2 pt)

o Reduce by $50 \%$ (1 pt)

o No potable use or no irrigation (1 pt)

- Innovative wastewater technologies (1 pt)

- Water use reduction (2 pt)
o $(20 \%)$
o $(30 \%)$

\section{Energy and atmosphere (17 points)}

- Fundamental commissioning (required)

- Minimum (code) energy performance (required)

- Fundamental Refrigerant Management (required)

- Optimize energy performance by $14 \%$ (new) or $7 \%$ (existing) buildings ( 2 pts, required as of June 26,2007 )

- Energy optimization (8 pts in addition to the 2 required above)

- On-site renewable energy (3 pts)

- Ozone depletion (1 pt)

- Measurement and verification (1 pt)

- Green power (1 pt)

\section{Materials and resources (13 points)}

- Storage and collection of recyclables (required)

- Building reuse (3 pts): 
o $75 \%$ reuse of building structure and shell excluding windows ( $1 \mathrm{pt}$ )

o $100 \%$ reuse of building structure and $50 \%$ of walls, floors, ceilings (1 pt)

- Construction waste reuse or recycling (by weight or volume) (2 pts):

o $50 \%$ diversion (1 pt)

o $75 \%$ diversion ( $1 \mathrm{pt}$ )

- Reuse of existing materials (by cost) (2 pts)

o $5 \%$ salvaged or refurbished materials ( $1 \mathrm{pt}$ )

o $10 \%$ salvaged or refurbished materials (1 pt)

- Recycled content (2 pts)

o Criteria vary in recent versions of LEED, but depend on value of pre- and post-consumer recycled content ( 2 pt)

- Use of local materials (2 pts)

o Fabrication shop within 500 miles $(800 \mathrm{~km})$ of building site and raw materials source within $500 \mathrm{miles}(800 \mathrm{~km})$ of building site, $10 \%$ (1 pt) or $20 \%$ (+1 pt).

- Rapidly renewable materials (1 pt)

- Certified Wood (1 pt)

Indoor environmental quality (15 points)

- Minimum indoor air quality (required)

- Environmental tobacco smoke control (required)

- Outdoor air delivery monitoring (1 pt)

- Increased ventilation (1 pt)

- Construction indoor air quality management (2 pt)

- Indoor chemical and pollutant source control (1 pt)

- Controllability of systems (2 pt)

- Thermal comfort (2 pt)

- Daylight and views (2 pt)

\section{Innovation and design process (5 points)}

Points for this category are awarded above and beyond the score of 64 points, and are described as rewarding strategies that go above and beyond the criteria for those points. Examples for up to four design points using steel construction include structure as finish, structure as plumbing, lightweight materials, recyclability, and potential for disassembly. 
